は, 金蠅 Phaenicia sericata 肉蠅 Sarcophaga peregrina, 黑蠅 Calliphora vomitoria の 3 種の蠅の卵, 幼虫を用い, ラッテに皮下 Myiasis を起さしぬ 24 時間後，48時閒 後, 72 時間後について経過観察し些かの所見を得たの

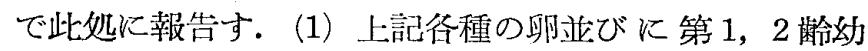
虫を度下に雨大創面閜鎖の場合，何れも Myiasis をみ

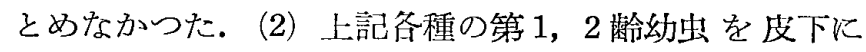
捚大創面開放の場合，何れも Myiasis を認めた。特に 金蛇例飞於て，皮下厷範棒の Myiasis を若起し 48 時 間後, 72 時間後に梦死与るものも認めた。(3) 病理組 織学的所見 皮下組織に細菌の感染と壊死をみとめた が，この塆死が細菌感染よりむしろ toxisch の影留に よるものであると考觉られる。（大阪市大・医動物）

\section{小ロ胃虫の中間宿主に関する研究：小林準三 Kobaya-}

shi, J. : Studies on the intermediate hosts of Habronema microstoma

小口胃虫 (Habronema microstoma) の中間宿主を調べ るため，各種のハェに対して小口胃虫卵の捕食笑験を行 つた，実験方法はよく成熟した小口胃虫の雌を解剖針で 細かく切つて内容を出乙，鏡検によりその胎虫の動小て いるのを確認してから，これを細磿した固型飼料にぬ ぜ，水でよく水り，八エの幼虫に捕食させた。笑験に供 したハエは全部で 16 種に及びこれらは予め卵から䁌化 させたものを固型飼料で育て，2〜3齿の幼虫に達した ものを使用した，尚，八ェ以外のもので，小口胃虫卵を 食う可能性のある種の昆虫に対しても捕食笑験を行つ た。捕食させたハエは羽化後, 頭部, 胸部, 腹部の 3 部 に分けて剖検し，胃虫仔虫の有無を調べたが，その結 果, サシバェ, サシバェ, ノイェバェの体内に胃虫仔 虫の発育しているのが認められた。サシバェ，ノサシバ エでは共に高率に等生が見られたが，中でもサシバェ体 内の胃虫仔虫はよく発育して拈り，ノサシバェではや〉 手つた。ノイェバェでは1例だけ胃虫\}虫の保有が認め られた。次に自然界の胃虫感染状態を調べるため, 千葉 県三里塚御料牧場と, 東京都内家畜衡生試験場に於て, 昭和 31 年 11 月から昭和 32 年 12 月迄の 14 力月間, 毎月 1 回ハエの採集を行い, 骨虫仔虫の保有状沉を調べた. その結果，三里塚に於ては昭和 31 年 11 月と，昭和 32 年 5 月から 12 月迄の 8 カ月間, サシバェ体内に充分に 発育した小日胃虫仔虫を保有しているものがあることが 分つた。これに対し，家畜德生試験場に於ては，同期間 中，胃虫仔虫を保有するハエは見られなかつた。

(東医歯大・医動物)
種々な実験法によるイエバエ各系紝の抵抗性比較：安富 和男 Yasutomi, K. : Values of the insecticide resistance of Musca domestica vicina due to different test methods

イエバェの抵挸性の度合を評価するには， $\mathrm{LD}_{50}$ で比 較する方法と，撒布基準量の有效成分を附的た面に接し

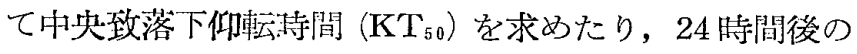
死亡率を求める方法などがある。ささらに， $\mathrm{LD}_{50}$ の場合 にも, 微量滴下法 (Topical application)と,濾紙などに種 々の薬量を撒布し，24時閭接触させる方法とがある. 㴼 者はこれらの諸方法で，秃統の異るイエバェについて笑

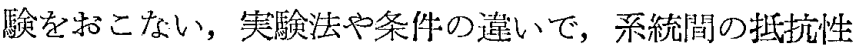
の度合の差が，如何なる傾向を示すか㭘討した. DDT：

Technical DD'T $10 \%$ を含有する市販粉剂を基準量撒布 (有效成分 $1.5 \mathrm{~g} / \mathrm{m}^{2}$ ) した面に接触させた KT-50では，高 梘系統と,最も強い紋別淘汰系統との開きは $1: 1.9$ 亿過 ぎなかつたが，濾紙面への Technical DDT アセトン液 撒布法 (有效成分 $2.5 \mathrm{~g} / \mathrm{m}^{2}$ ) では, 雨者の開きは1:2.3で あり,さらに, 濾紙法による 24 時間後の LD-50では, 1 : 2.9となつた。あた, 微量游下法に拈いて, Technical DDT では, 高柣系, 㝘根系, 福岡系は活心゙等しい值を 示し，紋別淘汰系は高柣系の $2 \cdot 1$ 倍を示した。純粋な p,p'-DDTを供試すると, 高柣系, 辰根系など,すべ て，60 $\gamma$ で死亡率が僅かに 30 32.0\%という低率であ つた. p,p'-DDT の效力が， Technical DDT に滛かに 秀るのは，どの方法でも認められた， $\gamma$-BHC：1\%市販 粉剤の基準量 (有效成分 $0.15 \mathrm{~g} / \mathrm{m}^{2}$ ) に対与る $\mathrm{KT}-50$ は, 最も弱小高柣系に比べて，福岡系は 6.7 倍，答根系は 17.3 倍という開きが見られた。微量滴下法による LD-50 では, 高柣系に比べて, 产根系は 42.3 偣, 福岡系は 37.6 倍を示し， LD-50でも濾紙法に上る場合には，微量 滴下法よりもこれらの開きが少なかつた. Dieldrin：粉 㓦の撒布基隻量（有效成分 $0.15 \mathrm{~g} / \mathrm{m}^{2}$ ) の $\mathrm{KT}$-50 法で, 最も感受性の高梘系に比べて, 海老名系は 23.1 倍, 福 岡系は 25.2 倍, 小櫃D系は 39.7 倍とい5数值を得た し，溜紙法による LD-50でもほ心゙同等の傾向が認めら れた。また, 微量滴下法では, 高柣系に比べて, 彥根系 は 105.1 倍という数值を示したが, 小樌 D, 袖ケ浦, 福 岡, 海老名の諸系統は, いずれも $60 \gamma$ で 10 40\%の死 亡率といら強度の抵抗性を示した。（予研・衞生昆虫） 